\title{
The Taxi Service Review: Malaysia Context
}

\author{
Amirul Fahmi R. \\ Lancaster University, Universiti Sultan Zainal Abidin \\ Email: a.razali@lancaster.ac.uk \\ Dr. David Hands \\ Lancaster University \\ Email:d.j.hands@lancaster.ac.uk
}

Doi:10.5901/mjss.2016.v7n4p

\begin{abstract}
In the majority city around the globe, taxis are an important element in mobility, which plays a significant role in transportation network. Surprisingly, this transportation mode carries no less than 40\% passengers, more than all other major public transportation such as busses and trains (Adrian T. Moore, 2008). There is consideration made by some public transportation analyst saying that using taxi service usually cost more than other public transportation mode, therefore, taxis should offer something that other public transportation means do not have (Salanova, Estrada, Aifadopoulou, \& Mitsakis, 2011). In circumstantial cases, taxi services are considered to be important towards certain articulation of the citizenry, such as the disabled, seniors, housewives, and the poor because they have much higher share of taxi trips than their percentage in the population (Moore \& Balaker, 2006). Nowadays, the majority of the cities around the world have regulated their taxi services such as controlling taxi entry into the market and implementing a fixed fare (Shaw, Gilbert, Bishop, \& Pruitt, 1983). Furthermore, in some major countries like UK's and US, they also set the requirements for taxi drivers, types of vehicles, finances and controlling the operations. But prior to implementing regulated taxi services, there are lots of research conducted regarding the taxi market regulation which has been done by multi agencies and other public transportation experts (Moore \& Balaker, 2006). This paper aim to review the Malaysian taxi services scenario. This paper also supported by the survey to see the congruity between the literature and outcome of the survey prior to the current situation of taxi services in Malaysia.
\end{abstract}

Keywords: Transportation Network, Public Transportation, Malaysian Taxi Services

\section{Introduction to Malaysia Context}

Today, most taxicabs found in Malaysia are from the national "local" car manufacturers e.g. Proton Saga BLM, Iswara, Wira, Waja, Naza Citra and from foreign car manufacturers e.g. Japan and Germany. The taxis are operating for various types of services in various locations all over Malaysia. The major consideration why Malaysian authorities, in this case is the Public Land Transport Commission (SPAD) for granting these types of cars for taxi uses, is to give the best user experience especially in comfortability and worthiness. Before the start of local car production in 1983-1986, the Mercedes-Benz 200, Mazda 323 of Ford Laser, Toyota Mark II X80 series and Opel Kadett were used. In 1989, most of the taxis were scrapped and Malaysian Taxi services start to use the national cars as their main taxis operating in the cities (SPAD (Land Public Transport Comission), 2012).

Table 1: Type and Model of car make authorized by SPAD (Land Public Transport Commission) in their Licensing Circular

\begin{tabular}{|l|l|}
\hline Type of Car & Model \\
\hline Saloon & Nissan Cefiro, Mercedez Benz E200, Hyundai Sonata 2.4L, Proton Perdana, Nissan Sylphy 2.0 CVTC \\
\hline Multi-Purpose Vehicle & $\begin{array}{l}\text { Toyota Alphard, Mazda 5LC, Naza Ria, Nissan Serena 2.0L, Toyota Innova, Mercedez Vito 119, Hyundai } \\
\text { Grand Starex, Naza Citra }\end{array}$ \\
\hline Budget Taxis & National Car with 1500 cc and above \\
\hline Executive Taxis & Any authorized car with 1950 cc and above \\
\hline
\end{tabular}

Most of the taxicabs run on diesel fuel but a smaller number runs on NGV (Natural Gas Vehicle). In Malaysia there are 
various issues regarding the NGV usage in taxis such as the maintenance services and the availability of NGV stations. The key issue that has always been highlighted by taxi drivers is on the filling stations, as there are only 2 NGV stations in Kuala Lumpur and which is insufficient to accommodate nearly 30,000 taxis operating around the city and Klang Valley (Amin Iskandar, 2015).

In a newspaper interview with a taxi driver, Mohd Zaidi Abas, 50, argued that the government should consider adding more NGV stations as each taxi needs to spend 10 to 15 minutes for refueling, and taxi drivers do not have any choices other than to wait for their turn and it is a waste of time (Asyraf Muhammad, 2016).

\section{The Reputation of Malaysian Taxi Services}

Malaysia taxi services has reportedly been marred due to the impoverished conduct by the local drivers, such as refusing to use taximeters, fleecing, and choosing preferred destinations of travel regardless to the locals or foreigners, while driving a poor maintained taxis (BERNAMA, 2015b). There are several large metered taxi companies are more likely to charge the user by using taximeter although they are managed by individuals with the company permit. Currently, newer taxi companies own and control their operations as well as the vehicles, whilst ensuring all drivers have undergone thorough background scrutiny. Alternatively, there is another technology-orientated option by using mobile apps like MyTeksi, TaxiMonger or Easy Taxi to secure taxi bookings. Through using these apps, the drivers are certified 'safe' and they are using the taximeters. This app also allowes the user to contact the assigned driver and track their journeys on a real time map (BERNAMA, 2015a).

Summary from a survey in June 2008, conducted by the Malaysian Expatriate Magazine on 200 foreigners from 30 different countries, found that Malaysian taxis were ranked the lowest among 23 countries in term of quality, courtesy, availability and expertise (Expat, 2008). The majority of the respondents gave bad impressions towards the Malaysian taxi services; with the survey criteria were assessed on a 10- point scale. They score a poorly average point with 4.58 meanwhile the neighboring country; Singapore scores an average of 8.44 . The most frequently raised complaints by the respondents towards the taxi services in Malaysia regardless from the locals or foreigners were the overcharging practices and refusal to take passengers who do not agree towards a flat rates fee (Expat, 2008). Also from the Expat report it stated that some of the respondent labeled the Malaysian taxi services as a 'national disgrace', and a 'threat to tourist'. In summary, the behavior of the unprofessional taxi drivers has tarnished the image of Malaysia especially among foreign tourist to the point where some begin resorting to pay an upscale taxi, which is more expensive, but offer better services such as Uber or Grab Car (AFP, 2008).

In addition to the fare issue, The Star Online in their newspaper report stating that the Malaysian as well as tourist in Malaysia need to be prepared on paying more for public transport (Meng, Choong, Lee, \& Gasper, 2015). This is due to the increase in taxi fares, which took an immediate effect from January 2015 and will be revised each year according to the SPAD chairman statement. Budget taxis in the Klang Valley and Johor Bharu region are charging 25 cents per 200 meters and 25 cents per 36 seconds although the flag fall ${ }^{1}$ will remain at RM3 for the first kilometer. A case study also reported in this newspaper saying that for example, a budget taxi that is stuck in traffic for an hour will take in RM25 (RM30 for those in Penang) from time-based charges alone, up from RM16.80 previously. This is likely to make taxi drivers more willing to face congestions (Meng, Choong, Lee, \& Gasper, 2015).

1 Flag Fall: Term used referring to the fix start fee of taxis 


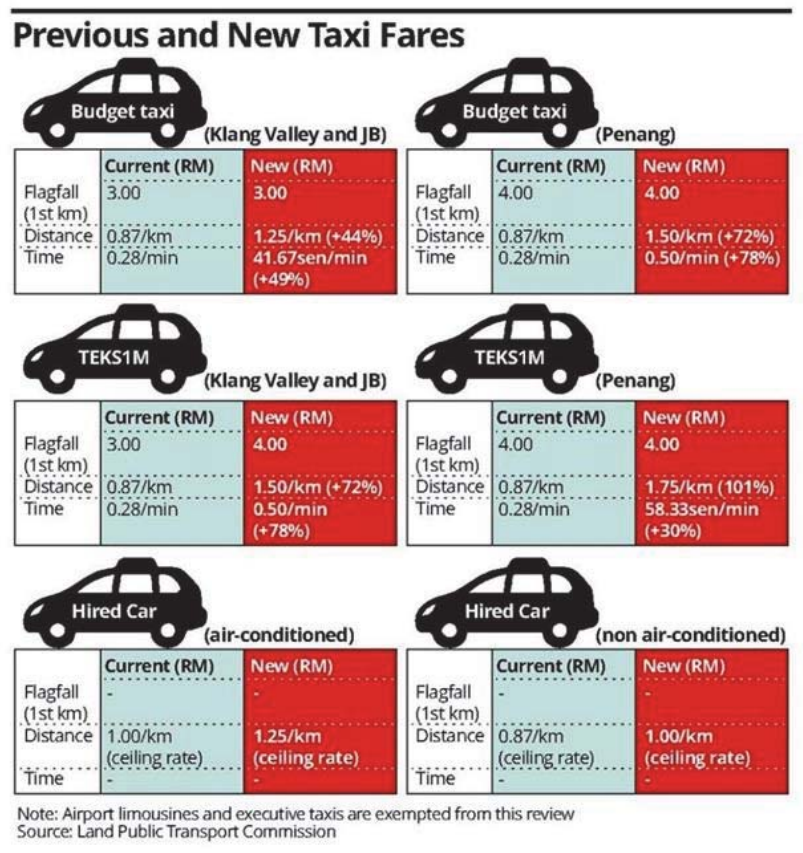

Figure 1: The previous and new taxi fares from the SPAD Public Transport Fare Circulars.

\section{Survey to Assess the Current User Perspective}

After examining and reviewing information focusing on the current Malaysian taxi services, this research was supported with a survey to understand and validate their current situation. Peculiarly to the literature did before conducting this pilot study, the outcome from the respondents was congruent in the previous researches. This questionnaire survey was distributed to specific groups of people that are currently using the taxi service within Malaysia. The areas of geographic focus were Kuala Lumpur and Klang Valley, Penang, and Johor Bahru, where the standard operation of taxi services is well observed and operated.

There is strong justification why this research concentrated on these 4 main cities for the case study instead of other large cities such as Alor Setar, Ipoh, Kota Bharu, and Kuala Terengganu etc. These 4 areas (KL, Klang Valley, Penang and Johor Bharu) are using SPAD regulated taxi services as their main service to operate in the city. Other cities allowed 'Kereta Sewa' or Hired car and Uber car to operate all together. Another reason is these 4 cities are the main tourist attraction in Malaysia; also the most suitable places to have diversity of people using the services and thus obtaining a larger representative range of data findings.

\subsection{Demographic of Surveyed Respondents}

Most of the respondents who participated in answering the questionnaire are female with $85.8 \%$ and $13.2 \%$ were male respectively; more than half of the respondents is single (56.6\%) and $24.5 \%$ were married. There is a study in 2004 with research on the pattern of selecting the transportation mode based on gender and this survey result is quite similar with the pattern conducted in this study (Roslan, 2004). The pattern is still valid today whereby women tends to use taxi more than men. Study findings suggested that the gender aspect plays a significant role in choosing the transportation mode, where men prefer to drive or ride their own vehicle. Women are different, as they prefer to act as a passenger instead. The null hypothesis in this research also proved that there is no significant difference between man and woman in choosing type of transportation to work, but women normally choose to act as a passenger even when they are using their own personal vehicle.Majority of the respondents (59.4\%) live in the suburban area, followed by $38.7 \%$ live in the 
urban area. The frequency of taxi service usage among the respondent, which marked "very often", is at $43.4 \%$ and another $34.9 \%$ saying they always use the service. It is reported that there are 827,000 user every day and the figure rises by $20.8 \%$ in 2012 and is rising every year. The reason why people choose public transportation rather than using their own vehicle is mainly to avoid traffic congestions and limited parking spaces at work place (Malaysia, 2014).

\subsection{Frequency and Purpose of Travel}

The frequency of taxi usage among users has been classified into 2 different categories, which depends on the specific time and day. As expected, most of the taxi usage is early in the morning, which represents $80.2 \%$ of the respondents, and during the evening, says $98.1 \%$ of them. From this figure, the frequent time of taxi usage ${ }^{2}$ is during the period where people went to work early in the morning and going back home in the late evening. This result also shows that the usage is significantly high during the weekdays except for Friday, the last day of working days with only $36.8 \%$, and slightly low during the weekends. It is proven that people are using taxis for the purpose of going to work or scheduled activities such as going to class and meetings that is reflected by $73.6 \%$ of respondents of this survey. In the same report stated before, the taxi usage normally rises more than $9 \%$ during peak hour and in the evening (Malaysia, 2014).

\subsection{Taxi Services in General}

Most of the respondents commented that hailing taxis by the street is the preferred way, with $80.2 \%$ saying that they prefer to use this method. With this amount of user hailing taxi from the street, the condition of taxi stops should be convenient, applicable and match the amount to accommodate this need. Apparently, most of the users spend more times waiting for taxis as there were less appropriate taxi stops in the city area, and most of the time, people prefer to wait at the bus stop in order to obtain a taxi, and it is against the law (Amin Iskandar, 2015). Giving quite a number of responses getting the taxis by phone call with $11.3 \%$, it is coherent that with the help of new technology and application on the smartphones today, Malaysian moved to use the electronic ways of getting the taxis, detecting the taxis using the apps, and phoned the closest taxi at their areas (Malaysia, 2014). Waiting the taxi is the other issue, where most of them say that they have to wait around 10-15 minutes in order to get that service. The ideal time of waiting the taxis is actually just around 2 minutes during normal hours, and around 7 minutes during peak hours, because it is by design whereby taxi is relatively easy to come by (Steinmetz, 2015).

The average taxi journey time says $67.9 \%$ of the respondents is about $30-44$ minutes. It is reported in news that every day, the average amount of travel recorded for taxis in the big cities such as Kuala Lumpur and Klang Valley is about 5.7 millions (Malaysia, 2014). Even though the distance between home and the intended area was not so far (suburban to urban area in average of 5-8 km), but this answer also illustrates that the traffic congestion is higher in urban areas where the taxi service operates, making travel time longer than expected. Longer time in taxi means the user needs to pay more for the service.

Refusing to use the taximeter is an issue that we frequently hear on the Internet, newspapers, blogs etc. Reported in news, a new application namely 'MeterOn' is still in its testing period, to study the effectiveness of the system. This system is to identify the taxi drivers who refuse to use the taximeter. This new application will allow the user to provide feedback and rating for the taxi driver, get to know where the driver is and studying their routine journey (BERNAMA, 2015a). On average, the SPAD (Land Transport Commissions) receive 400 complaints every month regarding taxi drivers who refused to use the taximeter.

\section{Malaysian, Taxi and the Services}

One of the past chairmen of Pacific Asia Travel Association (PATA), Tunku Iskandar had once discussed the Malaysian taxi services issues at an international level in 2008 in Hyderabad. He was also the former president of the Malaysian Association of Tour and Travel Agents. The taxi service issue in Malaysia often became a subject of discussion at the sideline. During the meetings in Hyderabad, the delegates asked him why the Malaysian government is allowing rogue taxi drivers to operate, even though they are charging passengers according to their whims and fancies instead of using the taximeter (Sulaiman, 2008). In response to that, during the same week of the PATA biannual meeting and travel mart in Hyderabad, there's a report wrote by Adri Ghani, a residing Malaysian in Saudi Arabia for a newspaper in Malaysia

${ }^{2}$ Based on the respondent's feedback from the pilot study, the frequent time of taxi usage is on Monday to Thursday for the weekdays, and Saturday on the weekend. The amount of taxi usage is more in the morning and late evening 
informing that there's an article in Saudi Arabia stating the taxi service in Malaysia as the 'world's worst cabs in tropical paradise' (Sulaiman, 2008). Furthermore, the newspaper argues that, 'Malaysia is wonderful, but its taxi touts and unchecked drivers come as an unpleasant surprise to tourists'. In addition to that, the taxi user in Malaysia who knew this current situation put the whole blame for what is happening on the government's current rental and monopoly systems for awarding taxi permits and routes.

It was not just the service; there is also a design issue towards the taxi in Malaysia. In one article found on Pepatung.com, they stated there are 5 major weaknesses towards taxi in KLIA2 (Kuala Lumpur International Airport 2). In the article, the 5 weaknesses were the non uniformity of taxis which confused the user, the taxi condition, messy drivers, driver's attitude and the cleanliness of taxis (Pepatung.com, 2015).

\section{Conclusion and Future Studies}

This paper has reviewed the current taxi service in Malaysia via conducting a literature review and by undertaking an exploratory pilot study. Initial conclusions suggest that the service needs to investigate this important criterion, which is 1) the quality of taxis, 2) ease of availability, 3) driver's courtesy level and job knowledge for future improvements. Other than service issues, the design of taxi need to be taken into account. As stated by John Koldowski, Managing Director of PATA, the first contact a tourist experiences with locals is often during airport transit to hotels thus creating a very, very strong first impressions, either good or bad, so, Malaysia needs to investigate the urgent needs of improving and developing their taxi design and services.

\section{References}

Adrian T. Moore, T. R. (2008). Regulatory reform at the local level: regulating for competition, opportunity, and prosperity by (Vol. 1974). AFP, T. S. M. H. (2008). Malaysia 's ' worst in the world ' taxis tarnish image. Retrieved from http://www.smh.com.au/news/news/worstin-the-world-taxis-tarnish-image/2008/09/19/1221331149000.html?page=fullpage\#contentSwap1

Amin Iskandar. (2015). Teksi dan Tahun Melawat Malaysia. Malaysiakini, 3. Retrieved from https://m.malaysiakini.com/columns/71186 Asyraf Muhammad. (2016, March 23). Stesen NGV Tidak Mencukupi. Sinar Online, pp. 1-4. Selangor.

BERNAMA. (2015a). Aplikasi "Meteron" Bakal Tangani Masalah Pemandu Teksi Tidak Guna Meter. Berita Selatan, Regional News, p. 2. Retrieved from http://www.bernama.com/bernama/state_news/bm/news.php?cat=sl\&id=1122406

BERNAMA. (2015b). Peningkatan tak setara perkhidmatan. MyMetro, p. 1. Retrieved from http://www.hmetro.com.my/node/38219\#sthash.LpDd7Z0G.dpuf

Expat, T. (2008). Malaysia Taxi Service Among the Worst. Retrieved from http://skorcareer.com.my/blog/malaysia-taxi-service-amongthe-worst/2008/07/01/

Malaysia, B. (2014). Peningkatan kadar penggunaan pengangkutan awam beri semangat kepada SPAD. Astro Awani. Malaysia. Retrieved from http://www. astroawani.com/berita-malaysia/peningkatan-kadar-penggunaan-pengangkutan-awam-beri-semangatkepada-spad-27816

Meng, B. Y., Choong, Y. E. W., Lee, P., \& Gasper, D. T. (2015). Fares increased for taxi , train and express bus services. The Star Online, pp. 15-17. Retrieved from http://www.thestar.com.my/news/nation/2015/03/20/public-transport-to-cost-more-faresincreased-for-taxi-train-and-express-bus-services/

Moore, A. T., \& Balaker, T. (2006). Do economists reach a Conclusion? Econ Journal Watch, 3(1), 109-132.

Pepatung.com. Lima Kelemahan Memalukan Perkhidm atan Teksi KLIA2 (2015). Retrieved from http://www.pepatung.com.my/semasa/lima-kelemahan-memalukan-perkhidmatan-teksi-klia2.htm

Roslan, A. R. Bin. (2004). Industri dan Kawasan Pengaruh Pekerjaan: Analisis Perjalanan ke Tempat Kerja di Kawasan Pasir Gudang, Johor.

Salanova, J. M., Estrada, M., Aifadopoulou, G., \& Mitsakis, E. (2011). A review of the modeling of taxi services. Procedia - Social and Behavioral Sciences, 20, 150-161. http://doi.org/10.1016/j.sbspro.2011.08.020

Shaw, L. C., Gilbert, G., Bishop, C., \& Pruitt, E. Taxicab Regulation in U . S . Cities Volume 2 : Case Studies (1983).

SPAD (Land Public Transport Comission). (2012). Kajian Kadar Tambang Teksi - Kertas Interaksi.

Steinmetz, K. (2015). 5 Reasons You Should Download a Taxi- Hailing App. Francisco, San York, New City, New York Francisco, San, p. 5 .

Sulaiman, Y. (2008). Malaysia tourism problems houn d PATA travel delegate in Hyderabad. ETN Global Travel Industry News. Kuala Lumpur. Retrieved from http://www.eturbonews.com/5273/malaysia-tourism-problems-hound-pata-travel-delegate-hyderabad 